\title{
REVISITING A CULTURE OF TOLERANCE RELATING TO RELIGIOUS UNFAIR DISCRIMINATION IN SOUTH AFRICA (PART 2) ${ }^{1}$
}

\author{
Radley Henrico \\ BProc LLB LLM LLD \\ Senior Lecturer, Public and Procedural Law \\ University of Johannesburg \\ Advocate of the High Court of South Africa
}

SUMMARY

In Part 1 of this article the need to reconsider whether merely tolerating diversity in a multicultural and pluralistic secular South African society is sufficiently addressed. Transformative constitutionalism is the vanguard of ensuring a substantive change in our democratic order. Such change brought about as a result thereof would be meaningless if it failed to embrace the fact that the proverbial South African "rainbow nation" showcases an array of religions from various walks of life. Secularism, multicultural diversity and the necessity of having to live together are a reality, filled with the ever-present possibility of dispute, whether in civil society or the workplace. Ubuntu is instrumental to the success of transformative constitutionalism; especially when effect to its underlying principles is given impetus by the collective. This article is divided into two parts. In Part 1, tolerance was viewed in terms of the origin of the term; its meaning of forbearance and putting up with differences. The question was posed whether commitment to true democracy is not better aligned to the notion of celebration rather than toleration. This article looks at tolerance against the backdrop of Ubuntu and the imperative that we care for others not due to a sense of forbearance but rather through acclamation of a spirit of celebration of our differences. The case of City of Tshwane Metropolitan Municipality $v$ Afriforum provides a crucial plank from which the notion of celebration, as opposed to mere toleration, should be embraced.

1

\section{INTRODUCTION}

The purpose of this article is to examine the proper meaning of the concept of toleration in respect of religious unfair discrimination in South Africa. As a multicultural and pluralistic society the "rainbow nation" of our society is one

This article draws on the unpublished LLD thesis by the author titled "Religious Discrimination in the South African Workplace" (North-West University, Potchefstroom 2017). 
that is representative not only of the secular but also of various religious interests. The commitment to democratic change places a high premium on transformative constitutionalism. Part 1 of this article examined the need to reconsider embracing toleration as a means to address the eclectic differences of our civil society which also extends into the workplace. It has been contended that true commitment to recognising other differences is celebration as opposed to toleration. This article argues that Ubuntu is an essential catalyst to the success of transformative constitutionalism in that it demands a collective social change toward a more egalitarian society: one in which all role-players are afforded a participatory role. Crucial to the realisation of substantive equality in our society is the need of recognition that we are united as a people, society, and country through our diversity. It is argued further that differences must conceptually no longer be excluded but included by way of recognition and accommodation through the optic of celebration. Moreover, differences that exist between individuals are no longer aspects of human identity for which any individual should be subjected to humility or unfair discrimination. Neither should such differences merely be tolerated. They must be accounted for and celebrated in our constitutional democracy. An analysis of the City of Tshwane Metropolitan Municipality $v$ Afriforum ${ }^{2}$ decision makes clear the imperative to embrace the celebration as opposed to toleration of differences.

2

\section{TRANSFORMATIVE CONSTITUTIONALISM AND THE NEED TO CELEBRATE DIVERSITY}

It is widely understood that the South African democratic dispensation is premised on the concept of transformative constitutionalism. ${ }^{3}$ This requires a

\footnotetext{
20169 BCLR 1133 (CC).

As coined by Klare "Legal Culture and Transformative Constitutionalism" 1998 SAJHR 171 and subsequently popularised by jurists and scholars in South African jurisprudence. See, eg, Mureinik "A Bridge to Where? Introducing the Interim Bill of Rights" 1994 SAJHR 31 3337; Pieterse "What Do We Mean when We Talk about Transformative Constitutionalism?" 2005 SA Public Law 156-160; Rapatsa "Transformative Constitutionalism in South Africa: 20 Years of Democracy" 2014 Mediterranean Journal of Social Sciences 887 889; Le Roux "The Aesthetic Turn in the Post-Apartheid Constitutional Rights Discourse" 2005 JSAL 101 105-110; Langa "Transformative Constitutionalism" 2006 Stell LR 351 353-356; Van Marle "Transformative Constitutionalism as/and Critique" 2009 Stell LR 286 288-290; Liebenberg "Needs, Rights and Transformation: Adjudicating Social Rights" 2006 Stell LR 5 7; Davis Democracy and Deliberation: Transformation and the South African Legal Order (1999) 178; Zitke "Stop the Illusory Nonsense! Teaching Transformative Delict" 2014 Acta Academica 52 63-65; Qozoleni v Minister of Law and Order 1994 (3) SA 625 (E) 634E-F; Pharmaceutical Manufacturers Association of SA: In Re Ex Parte Application of the State President of the RSA 2000 (2) SA 674 (CC); Bato Star Fishing (Pty) Ltd v Minister of Environmental Affairs and Tourism 2004 (4) SA 490 (CC); Minister of Health v New Clicks South Africa (Pty) Ltd 2006 (2) SA 311 (CC); Matatiele Municipality v President of the RSA 20071 BCLR 47 (CC) par 100. See also Langa 2006 Stell LR 351-353; Bishop and Brickhill "In the Beginning Was the Word': The Role of the Text in the Interpretation of Statutes" 2012 SALJ 681 711ff; Fagan "Section 39(2) and Political Integrity" 2004 Acta Juridica 117 134-135; Wallis "What's in a Word? Interpretation through the Eyes of Ordinary Readers" 2010 SALJ 673 690; Budlender "Transforming the Judiciary: the Politics of the Judiciary in a Democratic South Africa" 2005 SALJ 715718.
} 
change from a former authoritarian system of apartheid to a system characterised by a culture of justification.

Karl Klare ${ }^{5}$ has explained transformative constitutionalism to mean

"a long-term project of constitutional enactment, interpretation, and enforcement committed (not in isolation, of course, but in a historical context of conducive political developments) to transforming a country's political and social institutions and power relationships in a democratic, participatory and egalitarian direction. Transformative constitutionalism connotes an enterprise of inducing large-scale social change through non-violent political processes grounded in law ... In the background is an idea of a highly egalitarian, caring, multicultural community, governed through participatory, democratic processes ..."

What is envisaged is a change initiated by a process of participation by role-players in our society ${ }^{7}$ in a peaceful manner, activating social change through legal means in a spirit of equality and care. ${ }^{8}$ Transformative constitutionalism also assists in the interpretation of our Constitution text in a manner that advances our jurisprudence. ${ }^{9}$ The extent to which our courts,

4 The notion of a paradigm shift from an authoritarian culture to one which is justificatory is one which was captured by Mureinik 1994 SAJHR 31.

5 Klare 1998 SAJHR 146; Van Marle 2009 Stell LR 288-289; Davis and Klare "Transformative Constitutionalism and the Common and Customary Law" 2010 SAJHR 403 408-412; Christiansen "Transformative Constitutionalism in South Africa: Creative Uses of Constitutional Court Authority to Advance Substantive Justice" 2010 Journal of Gender, Race \& Justice 575 581-591; Roux "Transformative Constitutionalism and the Best Interpretation of the South African Constitution: Distinction without a Difference?" 2009 Stell LR 258 259. Also see Honore "Social Justice" 1962 McGill LJ 77.

6 Klare 1998 SAJHR 150. Author's own emphasis added.

7 Various role-players in our society include persons such as government, business, labour, educators, civic organisations. See Van der Westhuizen "A Few Reflections on the Role of Courts, Government, the Legal Profession, Universities, the Media and Civil Society in a Constitutional Democracy" 2008 SAJHR 251; Vorster "Managing Corruption in South Africa: the Ethical Responsibility of Churches" 2012 Scriptura 133; Davis and Le Roux "Changing the Role of the Corporation: A Journey Away from the Adversarialism" in Le Roux and Rycroft (eds) Reinventing Labour Law: Reflecting on the First 15 Years of the Labour Relations Act and Future Challenges (2012) 323-325.

8 Currie and De Waal The Bill of Rights Handbook (2005) 150; Meyerson Jurisprudence (2011) 139-141; Ackermann Human Dignity: Lodestar for Equality in South Africa (2014) 24; Du Plessis "The Status and Role of Legislation in South Africa as a Constitutional Democracy: Some Explanatory Observations" 2011 PER 92 94; O'Regan "Text Matters: Some Reflections on the Forging of a Constitutional Jurisprudence in South Africa" 2012 Modern LR 1-72; Klare 1998 SAJHR 171ff; Cooke "The Road Ahead for the Common Law" in Andenas and Fairgrieve (eds) Tom Bingham and the Transformation of the Law: A Liber Amicorum (2011) 691; Bilchitz and Williams "Religion and the Public Sphere: towards a Model that Positively Recognises Diversity" 2012 SAJHR 146 159; Investigating Directorate: Serious Economic Offences v Hyundai Motor Distributors 2001 (1) SA 545 (CC); Bishop and Brickhill 2012 SALJ 711; Wallis 2010 SALJ 690; Budlender 2005 SALJ 718; Henrico "Understanding the Concept of 'Religion' within the Constitutional Guarantee of Religious freedom" 2015 TSAR 784-803; Henrico "Revisiting the Rule of Law and the Principle of Legality: Judicial Nuisance or Licence?" 2014 TSAR 742.

9 In this regard see Joseph $v$ City of Johannesburg 2010 (4) SA 55 (CC) par 25-43 in which Skweyiya J, for the majority, used the concept of a "special cluster of legal relationships" to find that administrative law operates to govern relationships beyond the narrow confines of the law of contract. By doing so, he found that the poor tenants who were the claiman applicants had a procedural right under administrative law to receive a pre-termination notice from City Power. Also see Rail Commuters Action Group v Transnet Ltd t/a Metrorail 2005 (2) SA 359 (CC) par 80. 
legal interest practitioners ${ }^{10}$ and/or public interest groups ${ }^{11}$ should be involved as catalysts in bringing about social change through transformative constitutionalism is and will in all likelihood always be the subject of criticism and debate. ${ }^{12}$ Such criticism should be discounted on the following basis. First, our Constitutional Court has demonstrated its ability and aptitude in engaging with socioeconomic rights disputes as evidenced in the judgments handed down. ${ }^{13}$ So too has it handed down judgments which express a concern for the vulnerable, poor and those in need, and in this way demonstrated a concern about social change and equality. ${ }^{14}$ Second, the positive and relevant contribution to be made by interested role-players should not be dismissed. ${ }^{15}$ Irrespective of how we wish to interpret or label transformative constitutionalism, as an imperative it translates into the notion that "we live in a world we ourselves create" old humanist theories that the success of society depends on its social development, enlightenment and "transforming human thought". ${ }^{17}$ Surely the advancement of our jurisprudence, as read against the values and principles of our Constitution, would be meaningless if it cannot be said that it is actually making a difference in the lives of the people of our country. To this end, it means that freedoms should be guaranteed and realised. It also means that effect should be given to social justice, ${ }^{18}$ in other words, social

10 Such as human rights litigators or public interest legal advocates.

11 Such as NGOs.

12 See Socio-Economic Rights Institute of South Africa (SERI) 2015 Public Interest Legal Services in South Africa Report 2015 www.raith.org.za/docs/Seri_Pils_report_Final.pdf (accessed 2016-11-03) especially authorities cited fn 20-25.

81 See eg, Government of the RSA v Grootboom 2001 (1) SA 146 (CC) par 23; Khosa $v$ Minister of Social Development 2004 (6) SA 505 (CC) par 46-48; Minister of Health $v$ Treatment Action Campaign (2) 2002 (5) SA 721 (CC) par 38.

14 See eg, President of the RSA v Hugo 1997 (4) SA 1 (CC) par 32-52; Zondi v MEC for Traditional and Local Affairs 2006 (3) SA (CC) par 40, 55, 76-78, 82; Joseph $v$ City of Johannesburg supra par 25-30; Minister of Public Works v Kyalami Ridge Environment Association 2001 (3) SA 1151 (CC) par 34-41, 55-57, 99-112; Allpay Consolidated Investment Holdings v CEO of the South African Social Security Agency (No. 1) 2014 (1) SA 604 (CC) par 47, 52-55; Allpay Consolidated Investment Holdings v CEO of the South African Social Security Agency (No. 2) 2014 (4) SA 179 (CC) par 32-34, 47, 50, 55-60, 64$67,71,77$.

15 See Chief Justice Mogoeng's sentiments in his OR Tambo memorial lecture to the effect that "all South Africans can make a contribution to improve the situation in our country" Jordaan "Please Stop this Insatiable Hunger for Money - Chief Justice Mogoeng" 28 October 2016 Times Live http://www.timeslive.co.za/local/2016/10/28/\%E2\%80\%98Pleasestop-this-insatiable-hunger-for-money\%E2\%80\%99---Chief-Justice-Mogoeng; see also Albertyn and Goldblatt "Facing the Challenge of Transformation: Difficulties in the Development of Indigenous Jurisprudence of Equality" 1998 SAJHR 248 249, 253-254.

16 A quotation by Johann Herder referred to by Berlin "Herder and the Enlightenment" in Berlin, Hardy (ed) The Proper Study of Mankind: An Anthology of Essays (2012) 359.

17 See Berlin "Herder and the Enlightenment" in The Proper Study of Mankind: An Anthology of Essays 360; Garvey and Stangroom The Story of Philosophy: A History of Western Thought (2016) 62; Dworkin Law's Empire (1988) 189; Lavine From Socrates to Sartre: The Philosophic Quest (1984) 9-13; in this regard we must also recall the profound effect that the writings on liberty, equality and fraternity by Jean-Jacques Rousseau had on the French Revolution.

18 It falls outside the purview of this research to focus on theories of "social justice". For purposes of this research "social justice" is taken to mean a sense of addressing what is fair and just in our society and in the labour context, particularly the disparities of power with reference to normative concepts of equality, freedom and human dignity. For further reading see Smit "The Contribution of Labor Law and Non-Discrimination Law to Empowerment and 
transformation by providing the realisation for the people of South Africa of a new society in which the rights to equality, freedom and human dignity are upheld by addressing, inter alia, the socioeconomic needs of the underprivileged, poor, uneducated and vulnerable.

In everyday parlance, South Africa is referred to as the "rainbow nation". ${ }^{19}$ The varied colours of this rainbow metaphorically mirror the rich diversity of cultures emblematic of South African society. Express recognition of this diverseness is found in the Preamble of the Constitution, which provides that "South Africa belongs to all who live in it, united in our diversity". ${ }^{20}$ Reference to the adjective "united" is significant because it is mentioned again in the Preamble in the context of the Constitution being adopted as the "supreme law of the Republic" so as to "build a united and democratic South Africa" ${ }^{21}$

The Zulu proverb umuntu ngumuntu ngabantu "a person is a person because of (other) people" (usually referred to as the principle of Ubuntu) ${ }^{22}$ has been pointed out as encapsulating a "sense of community and the interdependence of the members of a community". ${ }^{23}$ More particularly, Ubuntu - the obligation to care for family members and a sense of community responsibility - is "[a] vital and fundamental value in [the] African social system" recognised in the African Charter on Human and Peoples'

Social Justice in an Unequal Society: A South African Perspective" 2013 Int Journal of Comparative Labour Law and Industrial Relations 375390 and especially the description accorded to social justice fn 71; Du Toit "Industrial Democracy in South Africa's Transition" 1997 Law, Democracy \& Development 39-40; Gericke "The Interplay between International Law and Labour Law in South Africa: Piercing the Diplomatic Immunity Veil" 2014 PER 2600 2603; Twyman "Finding Justice in South African Labour Law: the Use of Arbitration to Evaluate Affirmative Action" 2001 Case Western Reserve Journal of Int Law 307 324-330; Makhubele and Ford "White Paper on A Comparison of Labour Laws Worldwide, Their Impact on the Global Workforce and South Africa's Labour Law Disposition" 2015 https://c.ymcdn.com/sites/apso.site (accessed 2015-07-15) 18-25.

19 The term was first used by Archbishop Desmond Tutu in describing the new South African democratic order in which people of diverse cultures and ethnicities could come together and be united as "one of the most culturally diverse nations of the world". See Kellerman "The Rainbow Nation" Dreams to Reality 2014-07-23 www.dreamstoreality.co.za/the-rain bow-nation (accessed 2016-12-27). Also see Buqa "Storying Ubuntu as a Rainbow Nation" 2015 Verbum et Ecclesia 1-8; Herman "Jacob Zuma and Minority Groups in Post-Apartheid South Africa: An Examination of his Reconciliation Policy toward the Afrikaners" 2011 AJPSIR 10-20. This diversity is underscored by the fact that in terms of $S 6(1)$ of the Constitution eleven (11) official languages are recognised in the RSA.

20 Author's own emphasis added.

21 Author's own emphasis added.

22 As referred to by Langa J in MEC for Education: KwaZulu Natal v Pillay 2008 (1) SA 474 (CC) par 53 who, it is submitted, by necessary inference aligned the concept "we are not islands unto ourselves" with the more familiar notion coined by John Donne's famous line that "No man is an island ..." as it appears in his 1624 poem Devotions upon Emergent Occasions and Several Steps in my Sickness Meditation XVII.

23 Per Ngcobo $\mathrm{J}$ in Bhe $v$ Khayelitsha Magistrate 2005 (1) SA 580 (CC) par 163. Also see the interesting argument referred to in Winks "A Covenant of Compassion: African Humanism and the Rights of Solidarity in the African Charter on Human and Peoples' Rights" 2011 AHRLJ 447452 in which authors Cornell and Muvangua contend that ubuntu includes a social bond whereby through an "engagement and support of others ... we are able to realise a true individuality and rise above our biological distinctiveness into a fully developed person whose uniqueness is inseparable from the journey to moral and ethical development". 
Rights. ${ }^{24}$ Inexorably linked to Ubuntu, as stated in the death penalty case of $S v$ Makwanyane, ${ }^{25}$ are notions of respect for life and human dignity in the observation that the life of another is "at least as valuable as one's own". ${ }^{26}$ The notion of Ubuntu was earmarked in Makwanyane as "permeating the Constitution generally $\ldots$ and specifically the fundamental human rights". ${ }^{27}$ Madala $\mathrm{J}$ observed the following:

"In contrast to the apartheid legal order, in which parliamentary sovereignty demanded conservative and literal statutory interpretation by the judiciary, the post-apartheid order of constitutionalism requires courts to develop and interpret entrenched rights in terms of a cohesive set of values, ideal to an open and democratic society ... [T] his interpretation should be inclusive of South Africa's indigenous value systems, which relate closely to the constitutional goal of a society based on dignity, freedom and equality. While acknowledging that a function of the Constitutional Court is to protect the rights of vulnerable minorities.'

What may have formerly been a cause célèbre ${ }^{29}$ must now be accepted as being elemental to the diversified make-up of South Africa. ${ }^{30}$ In other words, individuals who are different, either as a result of an inherent characteristic $^{31}$ or due to circumstances ${ }^{32}$ or even lifestyle choices ${ }^{33}$ ought not to be singled out and objectified but should rather be included and embraced in our democratic and mosaic-like society. These differences, although alluded to as specific categories above, are highlighted merely as examples. They must, however, notionally not be understood as artificial rigid parameters. Instead, they should rather be conceived of as merging and co-mingling with the innate human identity of every individual which must be respected on account of its inherent human worth and value. ${ }^{34}$

24 Per Ngcobo $\mathrm{J}$ in Bhe $v$ Khayelitsha Magistrate supra par 166. The Charter, also known as the Banjul Charter, was adopted in Nairobi on 27 June 1981 and came into effect on 21 October 1986. It is an international human rights instrument that was duly signed and ratified by South Africa on 9 July 1996. 1995 (3) SA 391 (CC).

Par 217.

Par 237.

28 Par 306. Author's own emphasis added.

29 One need only refer to the previous arbitrary and unfair race classification system which prevailed in South Africa under the apartheid regime. Even sexual orientation was regarded in the main as taboo - so much so that homosexuality was punishable under the law. See llyayambwa "Homosexual Rights and the Law: A South African Metamorphosis" 2012 Int Journal of Humanities and Social Science 50 51-54.

30 Admittedly, instances of unfair discrimination on the basis of race, religion and even gender, unfortunately continue to manifest themselves. In this regard reference can be had to the Penny Sparrow matter, ANC v Sparrow [2016] ZAEQC 1 (10 June 2016); the case of Strydom v NG Gemeente Moreleta Park 200930 ILJ 868 (EqC) where a music teacher (who had been appointed as an independent contractor) fell victim to discrimination on the basis of his sexual orientation. On the other hand, these instances should come as no surprise given the multicultural fabric of our society and the potential of conflict arising therefrom on the basis of, inter alia, intolerance.

31 For eg, such as race, age, gender, ethnicity, sexual orientation, or birth.

32 For eg, such as religion, disability, marital status, or pregnancy.

33 For eg, such as culture, belief, or conscience.

34 See Ackermann Human Dignity: Lodestar for Equality in South Africa 9; comments made by Mahomed DP in AZAPO v President of the Republic of South Africa 1996 (4) SA 671 (CC) par 1; Brink $v$ Kitshoff 1996 (4) SA (CC) par 40; President of the RSA v Hugo supra par 41; 
The importance of recognising the latter gives effect to the notion of substantive equality ${ }^{35}$ which makes allowance for different treatment in respect of different persons, taking into account the attendant merits of each and every case. This is aptly described as follows:

"Equality is not simply a matter of likeness. It is, equally, a matter of difference. That those who are different should be differently treated is as vital to equality as a requirement that those who are like are treated alike.

There is thus a distinct relation between achieving substantive equality by recognising the need to make allowances not only for differences, but treating and providing relief for such differences in accordance with their merits. By so doing such differences are conceptually no longer excluded from our society; they are included by way of recognition and accommodation and notionally they are celebrated. ${ }^{37}$ The differences that exist between individuals are no longer aspects of human identity for which any individual should be subjected to humility or unfair discrimination, but rather features that must be accounted for and celebrated in a constitutional democracy. ${ }^{38} \mathrm{~A}$ culture of justification, upon which transformative constitutionalism is premised, is legitimised and realised through recognition of differences and the realisation of substantive equality. However, to what

Bato Star Fishing $v$ Minister of Environmental Affairs and Tourism supra par 36; Minister of Finance v Van Heerden 2004 (6) SA 121 (CC) par 26. See also Moseneke "Reflections on South African Constitutional Democracy - Transition and Transformation" Keynote address presented at the Mistra-Tmali-Unisa Conference on 12 November $2014 \mathrm{http}: / / c o n s t i t u t i o$ nallyspeaking.co.za/dcj-moseneke-reflections-on-south-african-constitutional-democracytransition-and-transformation/ (accessed 2016-08-05); Dugard Human Rights and the SA Legal Order (1978); Mathews Freedom, State, Security and the Rule of Law (1986); Swart "Apartheid Reparations: In Search of a Suitable Theoretical Foundation" 2013 SA Public Law 73; Henrico "The Role Played by Dignity in Religious-Discrimination Disputes" 2014 Obiter 24. Also see National Coalition for Gay and Lesbian Equality v Minister of Justice 1999 (1) SA 6 (CC) par 125-126; AZAPO v President of the RSA supra par 1.

35 See Du Toit, Cohen, Conradie, Cooper, Giles, Godfrey and Steenkamp Labour Relations Law: A Comprehensive Guide 6ed (2015) 656. For further reading, see Albertyn "Constitutional Equality in South Africa" in Dupper and Garbers (eds) Equality in the Workplace: Reflections from South Africa and Beyond (2009) 77 and authorities cited fn 16; Minister of Finance $v$ Van Heerden supra par 26; Minister of Home Affairs v Fourie 2006 (1) SA 524 (CC) par 60; Albertyn "Substantive Equality and Transformation in South Africa" 2007 SAJHR 253 257-258; Fredman "Providing Equality: Substantive Equality and the Positive Duty to Provide" 2005 SAJHR 163 168-169. Cf Wesson "Discrimination Law and Social Rights: Intersections and Possibilities" 2007 Juridica Int 74-82.

36 Du Toit et al Labour Relations Law 656 esp authority fn 30.

37 See Albertyn 2007 SAJHR 255ff; Chaskalson "Human dignity as a foundational value of our constitutional order" 2000 SAJHR 200; Minister of Home Affairs v Fourie supra.

38 See President of the RSA v Hugo supra; National Coalition for Gay and Lesbian Equality v Minister of Justice supra; Minister of Finance $v$ Van Heerden supra; Bato Star Fishing (Pty) Ltd $v$ Minister of Environmental Affairs and Tourism supra. In the case of Elauf $v$ Abercrombie \& Fitch 575 U.S. 2015, the Supreme Court of the US handed down judgment against the company in favour of the employee who was refused a job on grounds of wearing a headscarf in apparent conflict with the company's dress code. The ruling is said to be indicative of "a victory for our increasingly diverse society ..." (see Jameson "Supreme Court Rules against Abercrombie \& Fitch in Discrimination Case" 1 June 2015 The Huffington Post www. huffingtonpost.com/2015/06/01 supreme-court-abercrombie n 746453 4.html (accessed 2015-07-23). For further discussion on religion in a pluralistic society see Clark and Corcoran "Pluralism, Secularism, and Tolerance" 2002 Rhetoric \& Public Affairs 627; Ferrari "Religion and the Development of Civil Society" 2011 Int Journal for Religious Freedom 29. 
extent, if any, can it be said that transformative constitutionalism requires a sense of celebration of differences, as opposed to mere toleration?

Secularism, multicultural diversity and the necessity of having to live together as South Africans were referred to by Sachs $\mathrm{J}$ in Minister of Home Affairs $v$ Fourie. ${ }^{39}$ Similar sentiments were expressed by the Labour Appeal Court some years later in Kievits Kroon Country Estate (Pty) Ltd v Mmoledi ${ }^{40}$ in which the Labour Appeal Court stated the following:

"It will be disingenuous of anybody to deny that our society is characterized by a diversity of culture, traditions and beliefs. That being the case, there will always be instances where these diverse cultural and traditional beliefs and practices create challenges within our society, the workplace being no exception. The Constitution of the country itself recognizes these rights and practices ... What is required is reasonable accommodation of each other to ensure harmony and to achieve a united society."

Essentially what can be garnered from the above dictum is an exhortation to everyone in South Africa to live a life which is meaningful, rather than merely surviving, in the sense that there is mutual respect among fellow citizens. Irrespective of the degree to which someone holds a particular view, whether religious or secular, the purpose of the Constitution is to permit such views, however varied, to be held in a non-destructive manner without any sense or notion of mutual destructiveness. The latter would obviously be inimical to the interests of an open and democratic society. Moreover, the express reference to the capacity to manage and accommodate different views at once, some would argue, brings to mind the notion of having to tolerate. Both cases emphasise the need to accommodate differences. The former emphasises that this must be done in a manner that is non-destructive. The latter emphasises the notion of harmony as a result of accommodation that may result in a united society. ${ }^{42}$

The criticism against usage of the term "tolerance" is that it brings to mind more negative than positive connotations. Having to "put up with something" may very well mean that there is no alternative short of enduring a penalty or regime of displeasure. It is notionally associated with a transient concept in the sense that a certain state of affairs will only be endured for as long as it has to be withstood or suffered. An employee who describes his or her working conditions as tolerable essentially describes a lacklustre employment relationship - as does someone who describes their personal or intimate relationship with another individual in this way. To tolerate by

Supra; as quoted in s 2.1 of Part 1.

201211 BLLR 1099 (LAC).

Par 26.

42 For other judgments emphasising the need for accommodation of differences in our multicultural pluralistic society, see Christian Education South Africa v Minister of Education 2000 (4) SA 757 (CC) par 23; President of the RSA v Hugo supra par 41, 112; National Coalition for Gay and Lesbian Equality v Minister of Justice supra par 125-126; Bato Star Fishing $v$ Minister of Environmental Affairs and Tourism supra par 76; MEC for Education: Kwazulu Natal v Pillay supra; Strydom v NG Gemeente Moreleta Park supra par 25; Dlamini v Green Four Security 200611 BLLR 1074 (LC) par 10; Lewis v Media24 Ltd 201031 ILJ 2416 (LC) par 127-128; SACTWU v Berg River Textiles, a division of Seardel Group Trading (Pty) Ltd 201233 ILJ 972 (LC) par 38; Department of Correctional Services v POPCRU 2013 JOL 30347 (SCA) par 21-23. 
nature is inexorably associated with having to endure and put up with something, someone or a situation. Notionally, the term has strong associations with being compelled to do something rather than acting of one's own volition.

Thus, to use the verb "to tolerate" in the context of accommodating differences in a multicultural society to ensure harmony is inappropriate and non-suited. Attaining peace and maintaining harmony through means of tolerance, although not unrealistic, is unlikely to prevail for any length of time on account of the fact that beneath the veneer of tolerance is the tension of having merely to put up with a certain state of affairs. On the other hand, when multicultural differences are conceived of in terms of the verb "to celebrate" it has the potential of changing the manner in which our pluralistic society is viewed and even how the multicultural differences thereof are taken into account.

The notion of celebrating our multicultural diversity aligns itself closely with the paradigm of South Africa being a "rainbow nation". Reasonable accommodation is required to ensure harmony. Very often tolerance underscores the reasonable accommodation imperative. However, by substituting tolerance with celebration, the differences required to be accommodated essentially no longer are experienced as a burden. Instead, they serve as a means and a concrete example of a democratic dispensation activating its ethos of extolling the true essence of its diverseness; a diverseness which is inclusive and not exclusive. In this sense effect is given to the concept of Ubuntu in that we care for others not due to a sense of forbearance and tolerance but in a spirit of celebration of who we are as people and citizens capable of transforming South African society into a culture demonstrative of harmony, care, giving and concern for others.

If a spirit of celebration, as opposed to toleration, is to be adopted, the Constitutional Court in City of Tshwane Metropolitan Municipality v Afriforum which highlights the importance of Ubuntu has significant consequences. In delivering judgment for the majority of the court, Mogoeng CJ observed the following:

"All peace- and reconciliation-loving South Africans whose world-view is inspired by our constitutional vision must embrace the African philosophy of 'ubuntu'. 'Motho ke motho ka batho ba bangwe' or 'umuntu ngumuntu ngabantu' (literally translated it means that a person is a person because of others). The African world-outlook that one only becomes complete when others are appreciated, accommodated and respected, must also enjoy prominence in our approach and attitudes to all matters of importance in this country, including name-changing. White South Africans must enjoy a sense of belonging. But unlike before, that cannot and should never again be allowed to override all other people's interests. South Africa no longer 'belongs' to white people only. It belongs to all of us who live in it, united in our diversity. Any indirect or even inadvertent display of an attitude of racial intolerance, racial marginalisation and insensitivity, by white or black people, must be resoundingly rejected by all South Africans in line with the Preamble and our values, if our constitutional aspirations are to be realised.'

43 Moseneke DCJ, Bosielo AJ, Jafta J, Khampepe J, Madlanga J, Mhlantla J, Nkabinde J and Zondo J concurring.

44 Par 11. 
The case to do with matters relating to the renaming of street names in Pretoria. The Constitutional Court highlighted notions that are not only important for our overall constitutional dispensation but crucial to the underlying success of transformative constitutionalism. Apart from Ubuntu, the following notions, inter alia, were emphasised: tolerance, ${ }^{45}$ substantive equality; ${ }^{46}$ unity in diversity; ${ }^{47}$ protection of cultural identities ${ }^{48}$ and the need to transform society. ${ }^{49}$ An interesting aspect of the judgment is the extent to which there was a difference of approach by the Constitutional Court between the majority ${ }^{50}$ and the dissenting view ${ }^{51}$ in the protection to be afforded cultures. ${ }^{52}$ The Constitutional Court found that Afriforum had a prima facie right as a cultural association under section 31 of the Constitution. ${ }^{53}$ However, the irreparable harm Afriforum alleged they were and would continue to be subjected to, namely "toxicity that apparently comes with looking only at the names linked to other racial groups" ${ }^{54}$ was rejected by the Constitutional Court. The basis for doing so was a finding by the majority that while Afriforum had a right, like all other residents of a city, to participate in a consultative process with the municipality on the issue leading up to the change of street names, ${ }^{55}$ they had no right to have the old street names they treasured to be displayed indefinitely. ${ }^{56}$ Moreover, whatever sense of irreparable harm Afriforum stood to endure as a result of the change to street names was "neutralised" by the "equally important sense of belonging of the previously disadvantaged". ${ }^{57}$ Essentially a worldview of Ubuntu was articulated to which all South Africans must subscribe. ${ }^{58}$ In granting the appeal in favour of the Council and dismissing Afriforum's ultimate relief for an interdict, the Constitutional Court also admonished Afriforum for acting precipitously by launching proceedings against the Council in relation to a policy-related matter. ${ }^{59}$

45 Par 5, 11, 15-16, 22 per Mogoeng CJ. See also par 103 and 159 per Froneman and Cameron JJ; par 175 per Jafta J.

46 Par 18, 41 per Mogoeng CJ, par 157 per Froneman and Cameron JJ; par 166, 175 per Jafta J.

47 Par 6-7, 11, 14, 17-18, 22, 63, 65 per Mogoeng CJ, par 123, 126 per Froneman and Cameron JJ; par 176 per Jafta J.

48 Par 8, 16 per Mogoeng CJ; 126-129, 134 per Froneman and Cameron JJ; 169, 174 per Jafta J.

49 Par 8-9, 12, 19 per Mogoeng CJ; 161 per Froneman and Cameron JJ; par 171 per Jafta J.

50 Per Mogoeng CJ and Jafta J who at par 163-194 gave a separate but concurring judgment.

51 Per Froneman and Cameron JJ from par 79-162.

52 In City of Tshwane Metropolitan Municipality v Afriforum supra, Afriforum relied partly on s 31 of the Constitution as a cultural community of Afrikaans people who depended for their sense of being and belonging on the old names of the streets in Pretoria as a historical treasure and heritage being preserved (see par 25-28 and 50). S 31 was relied upon by Afriforum as a means of seeking enforcement of a restraining order against the Municipality preventing the Council from removing old street names in Pretoria (associated with the apartheid era and colonialism) and replacing them with names of persons symbolising South Africa's pursuit of justice, peace, unity and reconciliation (see par 22). Par 50 per Mogoeng CJ.

54 Par 58.

55 Par 60.

56 lbid.

57 Par 64.

58 Par 11, 15-18. See also par 123-137.

59 Par 71-75. See also par 101. 
The dissenting judgment raised concerns about the overall implication of the majority judgment for associations insisting upon cultural identity protection. ${ }^{60}$ Froneman $\mathrm{J}^{61}$ held as follows:

"That brings us to the second reason for this dissent. This is the implication that any reliance by white South Africans, particularly white Afrikaner people, on a cultural tradition founded in history finds no recognition in the Constitution, because that history is rooted in oppression.

Is culture inevitably tainted by historical injustice?

The broad premise of the first judgment is that the time has come to stop objections to name changes based on a cultural heritage that is rooted in a history of colonialism, racism and apartheid.

Afriforum may protest at the first judgment's characterisation of their historically rooted sense of place and belonging as 'highly insensitive to the sense of belonging of other racial groups'. It will jib at the suggestion that it "is divisive, somewhat selfish and does not seem to have much regard for the centuries-old deprivation of 'a sense of place and a sense of belonging' that black people have had to endure.'

The dissenting judgment points out that Afriforum had a view of history ${ }^{63}$ which appeared to be closer aligned with racism as opposed to culture under section 31 of the Constitution. ${ }^{64}$ However, the dissenting judgment proceeded to find that just because "we disagree so profoundly with Afriforum's view of history" ${ }^{\prime \prime 5}$ and it is better for them (Afriforum) to find their "sense of place and belonging"66 not in the past but under the Constitution in a shared future "united in diversity", 67 is insufficient to deny Afriforum their sense of belonging and protection under the Constitution. ${ }^{68}$ The rationale for this view is captured by the following dictum:

"What does concern us is the broad statement in the third judgment that embraces the implication of the first judgment, that any reliance by white South Africans, particularly white Afrikaner people, on any historically-rooted cultural tradition finds no recognition in the Constitution, because that history is inevitably rooted in oppression.

What does that mean in practical terms? Does it entail that, as a general proposition, white Afrikaner people and white South Africans have no cultural rights that pre-date 1994, unless they can be shown not to be rooted in oppression? How must that be done? Must all organisations with white South Africans or Afrikaners as members now have to demonstrate that they have no historical roots in our oppressive past? Who decides that, and on what standard?

This will be of concern not only to white South Africans, or to Afrikaners. It may also be of concern to those who take pride in the achievements of King Shaka Zulu, despite the controversy about his reign, and those who nurture the memory of Mahatma Gandhi's struggles in South Africa, despite some repugnant statements about black Africans. Our country has a rich and complex history. It has meaning for each of us, in diverse ways, which the

\footnotetext{
In terms of s 31 of the Constitution.

Cameron $\mathrm{J}$ concurring.

Par 117-119.

As expressed in their founding affidavit.

Par 122.

Par 123.

Ibid.

Ibid.

Ibid.
} 
Constitution accommodates and respects. The complexities of history cannot be wiped away, and the Constitution does not ask that we do so.

What is more, no case was made that Afriforum was a racist organisation, or that its members are all racists. They were never called to defend that accusation on the papers, nor in oral argument. The first and third judgments appear to assume that they are. Does this entail that, from now on, Afriforum and its members are branded as racist? If they are, they have not been given an opportunity to contest that allegation.

There are many cultural, religious or associational organisations that have roots in our divided and oppressive past. Are they all now constitutional outcasts, merely because of a history tainted by bloodshed or racism? If that is what the Constitution demands, we would wish to see a longer, gentler and more accommodating debate than happened here."

In support of the above reasoning, noting what the dissenting judgment observes in relation to Ubuntu is important, namely:

"With much of this we agree. But from a perspective of constitutional rights and values, these assertions are highly problematic. The Constitution allows the Executive and Legislature at national, provincial and local levels to formulate policies, legislate them into law, and execute and administer them when so done. They may choose to do so by changing the names of cities, towns and streets to reflect our diversity. Or they may decide not to do so. The Constitution allows them to make their own choice; it does not prescribe what choice to make. And the Constitution certainly does not allow the Judiciary to prescribe those choices.

Again, we agree that it would be beneficial if all South Africans approached matters with appreciation and respect for others. But the Constitution does not impose that as an obligation on citizens, either by enjoining the adoption of the ubuntu world-view, or otherwise. And, again, the Constitution does not allow the Judiciary to impose that obligation generally, least in the naming of streets, which falls within local authorities' constitutional competence.

There are other portions of the first judgment that suggest that the national project of attaining inclusivity, unity in diversity and reconciliation makes suspicious or doubtful the kind of sense of space and belonging that Afriforum claims. We have already pointed out that the Constitution generally does not mandate the imposition of a particular conception of this national project by the courts, and particularly not in relation to a local government competency to rename streets. But, on its own terms, this conception also carries within it the destruction of its objective of inclusivity.

Consider this. What is the effect of a failure to embrace ubuntu, by evincing appreciation of and respect for others? Does the person lose his or her constitutional protections? The first judgment seems to suggest Yes. This lies in its finding that even if Afriforum members had the kind of right they claimed - a sense of historic belonging and space - their loss of that sense can never qualify as irreparable harm. But this denial of that kind of possibly irreparable harm is not extended in our law to other infringements of rights whose loss cannot be quantified in material terms.

The issues that arise from the City of Tshwane judgment are not simple or without their complexities. In essence, the majority of the Constitutional Court found that Afriforum's cultural rights were of such a nature as not to warrant protection under section 31 of the Constitution. It could be argued that Afriforum's rights were rather restrictively interpreted in that merely on account of its associational interests with values that are shared by a small

9 Per Froneman and Cameron JJ par 130-134, footnotes excluded.

70 Par 136-139. 
minority. These must give way to the greater interests of Ubuntu and transformation under the Constitution.

Transformative constitutionalism serves a valid and urgent need for the success of our democracy. A change for the better is required and must take place wherever possible. It is through appropriate change that social justice can and must be delivered for our constitutional dispensation and the Constitution to be guaranteed legitimacy and stability. However, the manner in which such change is to be realised needs to be properly and carefully considered. If we contend that the differences are merely to be tolerated in the interests of achieving the "unity in diversity" commitment to toleration to the exclusion of unpopular cultures, beliefs or opinions. An analogy can be drawn with freedom of speech. Provided speech is not hate or racist speech, it should not merely be limited to the expression of ideas and thoughts that the majority hold. For speech to be truly free, it must also embrace matters which may be considered taboo, thought provoking or expressive of minority views. ${ }^{2}$ Accommodation in a "rainbow nation" must require that "mainstream" in addition to "minority" views are accommodated under the umbrella of pluralistic differences in a multicultural society. To declare that only mainstream ideologies, beliefs, cultures, ethnicities and views are seen as "appropriate" and "acceptable" is tantamount to exclusionism and non-accommodation. The mettle of our democratic society should not be tested only in terms of the extent to which we can boast the diverseness of our society, but rather of the true extent to which the most marginalised in our society are made to feel included as part of such society, and not unfairly discriminated against. In this sense, if emphasis is placed more on celebrating rather than tolerating differences, greater impetus is given to the conceptual notion of a "rainbow nation" unified in its diversity. Put differently, a conceptual celebration of differences, as opposed to mere tolerance thereof, may add more value to the overall sense of unification essential to democratic harmony and peace.

The notion of Ubuntu, insofar as it expresses the sense of togetherness and hence a collectiveness of inclusiveness, as opposed to exclusiveness, is integral to transformative constitutionalism. ${ }^{73}$ There can be no doubt that Ubuntu gives impetus to transformative constitutionalism in that it demands one to have regard to the imperatives of the Bill of Rights addressing the advancement of the sense of community and social cohesiveness - notions axiomatic to the success of a democratic order. Mokgoro ${ }^{74}$ makes the point that it behoves all responsible role-players in South Africa to take responsibility to ensure that the values of the Constitution are not merely

City of Tshwane Metropolitan Municipality v Afriforum supra par 79.

72 See Van Vollenhoven "The Right to Freedom of Expression: the Mother of Our Democracy" 2015 PER 2299 2303-2308; Webb "The Constitutional Court of South Africa: Rights Interpretation and Comparative Constitutional Law" 1998 Journal of Constitutional Law 205 235-239.

73 For further reading see Himonga, Taylor and Pope "Reflection on Judicial Views of Ubuntu" 2013 PER 369; Metz "Ubuntu as a Moral Theory and Human Rights in South Africa" 2011 AHRLJ 532 540-542; Schoeman "A Philosophical View of Social Transformation through Restorative Teachings - A Case Study of Traditional Leaders in Ixopo, South Africa" 2012 Phronimon 19 20-21.

74 A judge of the Constitutional Court from 1994 to 2009. 
empty and hollow words and sentences that appear in writing in the Bill of Rights, but are "swung into action" or "activated" through "creative law reform programmes, methods, approaches and strategies that will enhance adaptation" to aligning our society with the precepts of the values and principles of the Bill of Rights. ${ }^{75}$ The greater the number of sources informing the subject matter, the greater the chances of developing a more mature and reflective view enriched by a wealth and depth of insight. ${ }^{76}$ Important roleplayers concerning the dimension of religious freedom in the workplace are the worker and employer respectively. Their voices, taken as a dialogue in constructively addressing a problem as and when it arises in the workplace, would obviate the need for formal intervention in the form of official adjudication by a court. Should there be no constructive dialogue, or in the event of a stalemate, our workplace permits the parties to turn to the courts as arbiters of what would be a suitable solution to what may appear to be an intractable problem. What needs to be heeded at least from the dissenting judgment in City of Tshwane is that however small or minor the view in our society may be, and even if one does not necessarily endorse such view, ${ }^{77}$ it too needs to form part of the dialogue that contributes to building a future and better society. ${ }^{78}$

\section{CONCLUSION}

It has been argued in this article that South Africa's world reputation as the "rainbow nation" is a phenomenon and historical fact that each and every individual comprising its rich tapestry of diversity is permitted not only to participate in but also to celebrate. Differences of opinion, beliefs and religions will always exist. What matters is not that such differences exist, but rather that such differences are dealt with in a manner that ensures harmony and peaceful co-existence, whether in greater society or in a workplace scenario. Where differences are required to be accommodated, then optimally it should be done in a spirit of celebration of diversity on account of a greater sense of inclusivity, rather than exclusivity. Conceptually, this aligns itself closer with the paradigm of being "united in diversity" and gives impetus to a sense of genuine commitment to transformative constitutionalism. This is on account of the fact that it demonstrates an authentic stance in favour of Ubuntu and change for the better, even if it means including and embracing that which is different or a minority or marginalised view. The notion of tolerance is out of kilter with a genuine commitment to the essence of transformative constitutionalism. Tolerance signals acceptance as a mere tokenism of having to endure and put up with something which one would not voluntarily or actually do, if given

75 Mokgoro "Ubuntu and the Law in South Africa" 1998 PER 14-26.

76 Hoexter Chief Justice Langa and the Importance of Dissent Paper presented at the Acta Juridica conference in honour of the late former Chief Justice Pius Langa, Cape Town (1617 January 2014); Langa "The Emperor's New Clothes: Bram Fischer and the Need for Dissent" 2007 SAJHR 362.

77 Subject to the condition that there is no expression of harm, hate or violence to others.

78 This is underscored by Chief Justice Mogoeng's sentiments in his OR Tambo memorial lecture to the effect that "all South Africans can make a contribution to improve the situation in our country" (Jordaan http://www.timeslive.co.za/local/2016/10/28/\%E2\%80\%98Pleasestop-this-insatiable-hunger-for-money\%E2\%80\%99---Chief-Justice-Mogoeng). 
a choice. Whether we conceive of tolerance in terms of "thick" or "thin" tolerance, neither of the two concepts supports transformative constitutionalism in the sense of requiring all role-players to celebrate our "rainbow nation". Thus, differences and diverseness of religious beliefs and freedoms, whether in the workplace or greater society, must be accommodated under the broader expansive notion of celebration rather than mere toleration if resonance is to be given to an authentic understanding of our "rainbow nation". 